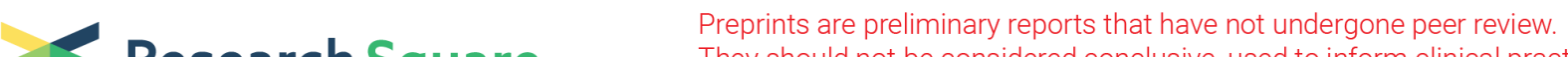 $\begin{array}{ll}\text { Research Square } & \text { They should not be considered conclusive, used to inform clinical practice, } \\ \text { or referenced by the media as validated information. }\end{array}$ \\ Do Bio-Insecticides Affect Only Insect Species? Behavior, Regeneration and Sexual Reproduction of A Non-Target Freshwater Planarian
}

\section{Laila Cristina Rezende Silva}

Federal University of Tocantins: Universidade Federal do Tocantins

Aline Silvestre Pereira Dornelas

Federal University of Tocantins: Universidade Federal do Tocantins

Althiéris de Souza Saraiva

Goiano Federal Institute: Instituto Federal Goiano

\section{Carlos Gravato}

Universidade de Lisboa

João Luís Teixeira Pestana

Universidade de Aveiro

\section{Amadeu Mortágua Velho da Maia Soares}

Universidade de Aveiro

Renato Almeida Sarmento ( $\square$ rsarmento@uft.edu.br)

Universidade Federal do Tocantins https://orcid.org/0000-0002-5379-9595

\section{Research Article}

Keywords: Beauveria bassiana, Bacillus thuringiensis, Acute Toxicity, Chronic Toxicity, Girardia tigrina, Freshwater invertebrates.

Posted Date: July 6th, 2021

DOI: https://doi.org/10.21203/rs.3.rs-532213/v1

License: (1) This work is licensed under a Creative Commons Attribution 4.0 International License. Read Full License

Version of Record: A version of this preprint was published at Environmental Science and Pollution Research on September 15th, 2021. See the published version at https://doi.org/10.1007/s11356-021-16493-8. 


\section{Abstract}

Bio-insecticides have been increasingly used worldwide as ecofriendly alternatives to pesticides, but data on their effects in non-target freshwater organisms is still scarce and limited to insects. The aim of this study was to determine the lethal and sub-lethal effects of the bio-insecticides Bac Control (based on Bacillus thuringiensis kurstaki - Btk) and Boveril (based on Beauveria bassiana - $\mathrm{Bb}$ ) on regeneration, behavioral and reproductive endpoints of the freshwater planarian Girardia tigrina. The estimated $\mathrm{LC}_{50-48 \mathrm{~h}}$ were $>800 \mathrm{mg}$ a.i./L for Btk and $60.74 \mathrm{mg}$ a.i./L for Bb. In addition, exposure to Btk significantly decreased locomotion and feeding activities of planarians (lowest observed effect concentration (LOEC) of $12.5 \mathrm{mg}$ a.i./L Btk) and fecundity rate ( $L O E C=3.12 \mathrm{mg}$ a.i./ $/ \mathrm{L} B \mathrm{k})$, whereas exposure to $\mathrm{Bb}$ significantly delayed regeneration (LOEC = $0.75 \mathrm{mg}$ a.i./L $\mathrm{Bb})$ and decreased fecundity rate $(1.5 \mathrm{mg}$ a.i./L $\mathrm{Bb})$ of planarians. Thus, both bio-insecticides induced deleterious sub-lethal effects on a non-insect freshwater invertebrate species. However, only Bb-based formulation affected the survival, fecundity rate and regeneration at concentrations below the maximum predicted environmental concentration ( $P E C=247 \mathrm{mg} / \mathrm{L}$ ). Thus, care should be taken when using such formulations as alternatives to chemical insecticides near aquatic ecosystems.

\section{Introduction}

Bio-insecticides have been increasingly used since the 80 's as alternatives to reduce the impacts on the environment and public health posed by application of chemical insecticides for the control of pests (Gupta and Dikshit 2010; Singh et al. 2018; Vivekanandhan et al. 2018). These biological compounds are based on microorganisms (bacteria, fungi, virus or protozoa) and have been considered ecofriendly due to their specificity, low toxicity, fast decomposition and efficacy when used in low concentrations (Gupta and Dikshit 2010; Kandpal 2014; EPA 2016). Therefore, they are considered safe to non-target organisms and humans (Mazid et al. 2011; Subbanna et al. 2019). Due to all their advantages and safety perception by consumers, the demand of microbiological products increased over the last 5 years showing a global market value of and US $\$ 5.2$ billion in 2020 in opposition to US $\$ 2.3$ billion in 2015 (Kumar 2015). According to the Environmental Protection Agency (EPA), 299 active ingredients have been registered and more than 1400 bio-based formulations were available in the market in 2016 (EPA 2016). Over the years, strains of Bacillus thuringiensis occupied prime position in biopesticide' market followed by entomopathogenic fungi, such as Beauveria bassiana (Thakore 2006; Olson 2015; Subbanna et al. 2019).

Bacillus thuringiensis kurstaki (Btk) is a facultative anaerobic gram-positive bacterium naturally occurring in soil, water, air and plants (Machado et al. 2017). It is known as an entomopathogenic bacterium that produces parasporal crystal proteins deathly toxic to insects after ingestion (Sanahuja et al. 2011; Castagnola and Stock 2014). The strains of $B$. thuringiensis (Bt) can produce different types of crystal proteins containing $\delta$ endotoxins that specifically affect certain orders of insects after previous solubilization and activation in their midgut (OECD 2012). The predicted environmental concentration in surface water $\left(P E C_{s w}\right)$ for different strains of $B$. thuringiensis kurstaki is lower than $100 \mu \mathrm{g}$ a.i. Btk/ L (EFSA 2012).

Beauveria bassiana $(\mathrm{Bb})$ is a filamentous fungus that belongs to the class of deuteromycetes (Sandhu et al. 2012; Berlitz et al. 2014). Briefly, it affects hosts through penetration of their cuticle by its conidia, followed by internal colonization of their tissues combining both mechanical pressure and enzymatic activities (Mascarin 
and Jaronski 2016). The grown hyphae invade the hemocoel of hosts and use nutrients of hemolymph producing toxins that ultimately lead to death (Sayed and Behle 2017; Rustiguel et al. 2018). This species of fungus is commonly found worldwide as a saprophyte in soils, an endophyte in plants and acting as entomopathogen for arthropods (Rehner et al. 2011; Berlitz et al. 2014). The predicted environmental concentration in surface water $\left(\mathrm{PEC}_{\mathrm{sw}}\right.$ ) for $B$. bassiana (different strain) range from 35,3 to $247,3 \mathrm{mg} / \mathrm{L}$ of commercial compound (EFSA 2015).

Despite all the advantages pinpointed to these bio-insecticides and the studies concerning their effects on target and non-target insects (Lajmanovich et al. 2015; Allgeier et al. 2019; Challa et al. 2019; Dornelas et al. 2020a), there is a lack of knowledge about their potential ecological effects to freshwater ecosystems (EFSA 2012; EFSA 2015). Moreover, some of these biological formulations of insecticides are also being used directly in aquatic ecosystems to control mosquito populations, that are vectors of human pathogens responsible for important diseases (Pelizza et al. 2010; Singh et al. 2018), which may increase their concentration in freshwater systems. Microbial insecticides-based Btk have been considered environmentally friendly, since they were considered harmless to non-target species due to its target-oriented mode of action (Álvarez and Biosca, 2017). In fact, $48 \mathrm{~h}$ and $96 \mathrm{~h} \mathrm{LC}_{50}$ previously estimated (Table 1) for vertebrate (fish and amphibians) species were high and above $100 \mathrm{mg}$ a.i. Bt/L (Becker and Margalit 1993; Karmrin 1997; WHO 1999), except for the frog Leptodactylus latrans with a $\mathrm{LC}_{50}$ of $22.45 \mathrm{mg} / \mathrm{L}$ (Lajmanovich et al. 2015). Moreover, studies performed with non-target insects showed that microbial insecticides were more acutely toxic for insects than other invertebrates, such as, the genus Hydra (Becker and Margalit 1993) (Table 1).

Thus, this study aims to determine the effects of the bio-insecticides Bac Control (based on B. thuringiensis kurstaki) and Boveril (based on B. bassiana) on the freshwater planarian Girardia tigrina Girard (Paludicola: Dugesiidae), not only to evaluate and compare their acute effects posed to planarians (mortality) with other studied species, but also to assess their sub-lethal effects using more sensitive endpoints, such as locomotion, feeding, regeneration and sexual reproduction. In fact, freshwater planarians have been successfully used in environmental toxicology studies to assess the sub-lethal effects caused by different contaminants on such endpoints (Ofoegbu et al. 2016; Rodrigues et al. 2016; Saraiva et al. 2018; Wu and Li 2018; López et al. 2019; Ofoegbu et al. 2019a, b; Saraiva et al. 2020; Dornelas et al. 2020b; Simão et al. 2020; Simão et al. 2021).

Freshwater planarian's characteristics like their broadly geographic distribution, easy experimental manipulation and maintenance in laboratory (Guecheva et al. 2003; Knakievicz 2014; Knakievicz and Ferreira 2008), and regeneration capacity (Reddien and Alvarado 2004), make them ideal to evaluate sub-lethal effects that might be more relevant in terms for environmental risk assessment. Moreover, planarians are aquatic invertebrates found in a range of water systems (Knakievicz et al. 2006; McConnell 1965; Tyler 2000) and they prey on insect larvae that are common targets of microbial insecticides (Allgeier et al. 2019; Benzina et al. 2018; Bordalo et al. 2020; Hart and Merz 1998; Reddien and Alvarado 2004; Vila-Farré and Rink 2018).

\section{Material And Methods}

\subsection{Bio-insecticides}


Bac-Contro ${ }^{\circledR}$ WP is a formulation based in spores of $B$. thuringiensis, Berliner $\left(25 \times 10^{9}\right.$ spores per gram) as active ingredient. This bio-insecticide was purchased from Vectorcontrol Indústria e Comercio de Produtos Agropecuários $L t d a$. Boveril ${ }^{\circledR}$ is a formulation based in the fungus strain ESALQ PL63 of B. bassiana (Bals.) Vuill., ( $1 \times 10^{8}$ conidia per gram) as active ingredient. This bio-insecticide was purchased from Koppert do Brasil Sistemas Biológicos Ltda.

\subsection{Test organisms}

Girardia tigrina was obtained from USP (University of São Paulo) and kept in the Laboratory of Ecotoxicology at the UFT (Universidade Federal do Tocantins - Functional and Applied Ecology Research Group) in ASTM (American Society for Testing and Materials) hard water medium (ASTM 1980) with constant aeration, controlled temperature $\left(22 \pm 1^{\circ} \mathrm{C}\right.$ ) and constant dark conditions. Planarians were fed with bovine liver ( $\mathrm{ad}$ libitum) for periods of 2 hours once per week followed by renewal of ASTM medium. Seven days before bioassays, planarians were not fed and active organisms with no signs of injuries were used for experiments.

\subsection{Acute tests}

Planarians were exposed to a range of concentrations of the active ingredient (a.i.) present in the formulations of $B$. thuringiensis kurstaki (Btk) and B. bassiana (Bb). Btk nominal concentrations were: $50 \mathrm{mg}$ a.i./L (39x $10^{9}$

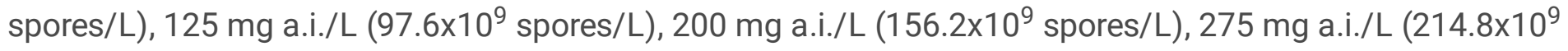

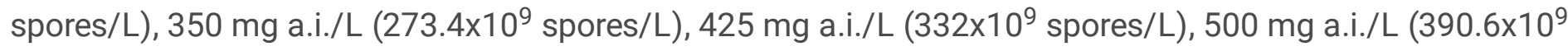

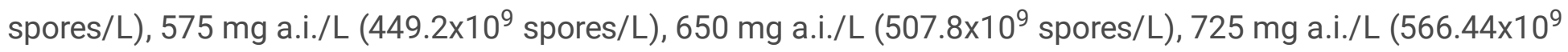

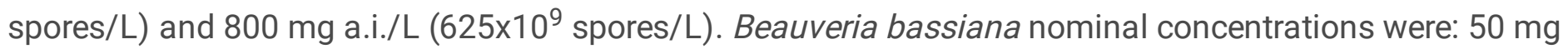

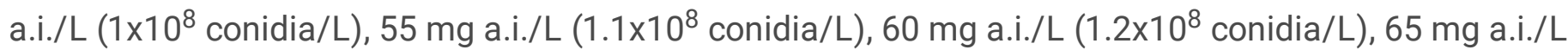

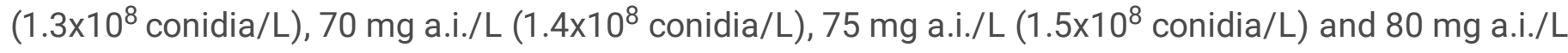
$\left(1.6 \times 10^{8}\right.$ conidia/L). A control treatment for each bioassay was performed using ASTM hard water only.

The length of test organisms used for the acute bioassays ranged from 8 to $10 \mathrm{~mm}$ and 25 organisms were used per experimental treatment (five planarians per replicate and 5 replicates). Exposure was carried out in Petri dishes $(90 \times 15 \mathrm{~mm})$, containing $20 \mathrm{ml}$ of each experimental solution and control treatment for each microbial insecticide. Planarians were exposed during 96 hours in statically system, with constant temperature $\left(22 \pm 1^{\circ} \mathrm{C}\right.$ ), in dark and without being fed. Mortality was checked at the end of 48 (to $\mathrm{Bb}$ and Btk) hours exposure. After the exposure period the number of dead organisms was registered for each replicate in order to allow estimation of Lethal Concentrations $\left(\mathrm{LCs}_{50}\right)$.

\subsection{Behavior and regeneration of planarians}

Planarians (8 to $10 \mathrm{~mm}$, total length) were exposed during 8 days to nominal concentrations (the highest concentration of the chronic test did not exceed $10 \%$ of the $\mathrm{LC}_{50}$ ) of $B$. thuringiensis $[1.56 \mathrm{mg}$ a.i./ $\mathrm{L}$

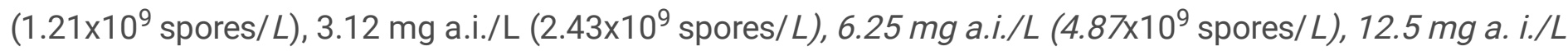




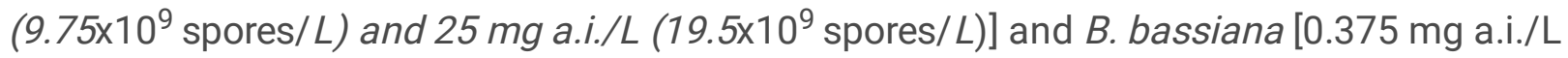

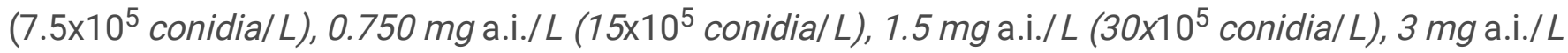
( $60 \times 10^{5}$ conidia/ $\left.L\right)$ and $6 \mathrm{mg}$ a.i./ $L$ ( $120 \times 10^{5}$ conidia/L). A contro/ treatment using ASTM hard water only was performed for each bioassay. Three replicates per condition (12 organisms per replicate) were used in a bottle glass containing $100 \mathrm{ml}$ of each experimental solution. The tests were performed at standardized conditions of temperature $22 \pm 1^{\circ} \mathrm{C}$, in the dark and without food.

\subsubsection{Locomotion}

The post-exposure effects of both bio-insecticides on planarian locomotor velocity ( $p \mathrm{LMV}$ ) were evaluated individually (using 12 organisms per condition) by placing the organism into a recipient $(\varnothing=35 \mathrm{~cm}$ ) containing ASTM hard water medium and covered with gridlines (spaced $0.5 \mathrm{~cm}$ per gridline). Locomotor velocity was measured by the number of crossed and re-crossed gridlines over a period of observation of 3 minutes. Results were expressed as the number of gridlines crossed per minute.

\subsubsection{Feeding activity}

Nine planarians per condition were individually placed into Petri dish containing $20 \mathrm{~mL}$ of ASTM hard water medium and 25 larvae of Chironomus xanthus (total length $0.6 \pm 0.1 \mathrm{~cm}, 2^{\circ}$ instars). The post-exposure feeding rate of planarians was determined by counting the number of chironomids larvae totally digested and consumed over 3 hours. Results of feeding rate were expressed as number of consumed larvae per hour.

\subsubsection{Regeneration}

After exposure, twelve organisms per treatment were decapitated with a precise single cut behind the auricles. After decapitation, each organism was individually placed in a Petri dish containing $20 \mathrm{~mL}$ of ASTM hard water only. Blastema regeneration (i.e. length in $\mathrm{mm}$ ) was observed after 48 hours decapitation and photoreceptors regeneration was monitored every 12 hours until complete regeneration, using a stereo microscopy $\left(\right.$ MIKROS $^{\circledR}$ ) with an eyepiece micrometer. Blastema length was expressed as $\mathrm{mm}$ after 48 hours regeneration, whereas photoreceptor formation was expressed as time in hours needed for formation of photoreceptors.

\subsection{Reproduction}

Sexual reproduction endpoints were determined on same conditions of Btk and Bb concentrations as described above, but the size of test organisms was $1.5 \pm 0.1 \mathrm{~cm}$, and the time of exposure 28 days. Four replicates per condition using ten organisms per replicate in a bottle glass containing $100 \mathrm{ml}$ were used for each experimental condition including controls. Planarians were fed once a week followed by renewal of test solutions. The number of cocoons and newborn planarians were registered daily in order to determine fecundity and fertility rates (Knakievicz et al. 2006). Fecundity was expressed as the number of cocoons 
produced divided by the number of planarians per treatment. Fertility was expressed as the number of offspring produced divided by total cocoons produced.

\subsection{Statistical analyses}

The 48h LCs $s_{50}$ of Btk and Bb in G. tigrina were estimated using four parameter logistic curve: $\mathrm{Y}=\mathrm{Bottom}+$ (Top-Bottom $) /\left(1-10^{\wedge}\left(\left(\operatorname{LogLC}_{50}-\mathrm{x}\right) *\right.\right.$ HillSlope $\left.)\right)$. For sub-lethal parameters, Kolmogorov-Smirnov and the Bartlett's tests were used to evaluate normality and homogeneity of variance of data, respectively. The effects of $B$. thuringiensis and $B$. bassiana on sub-lethal endpoints assessed in planarians were determined by oneway analysis of variance (ANOVA) followed by Dunnett's test. Locomotion data (B. bassiana) were transformed into rank $(Y)$ for correction of non-normal data. Non-parametric test (Kruskal-Wallis test) followed by Dunn's test was performed for analysis of $G$. tigrina photoreceptor regeneration. Statistical analysis was performed using the software GraphPad Prism version 7.0 for Windows (GraphPad Software, La Jolla, California, USA).

\section{Results}

\subsection{Lethal effects}

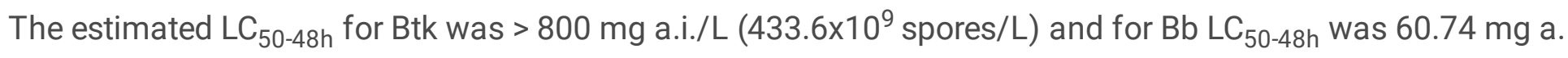
i./L (1.21×10 conidia/L) [95\% Cl: $59.61-61.89 \mathrm{mg}$ a.i./L]. It was also observed that the highest concentrations of both formulations induced body deformations in planarians followed by their total body disintegration.

\subsection{Sub-lethal effects}

Locomotor velocity was significantly decreased in planarians exposed to Btk with a LOEC of $12.5 \mathrm{mg}$ a.i/L $\left(F_{(5,66)}=13.17, p<0.0001\right.$, Figure $\left.1 a\right)$. Locomotor velocity was significantly altered by $-43.22 \%$ and $-54.23 \%$ in 12.5 and $25 \mathrm{mg}$ a.i./L of $B$. thuringiensis respectively. In contrast, no significant differences were observed on locomotion of planarians exposed to $\mathrm{Bb}$ when compared to the control treatment $\left(\mathrm{F}_{(5,66)}=1.81, p=0.31\right.$ Figure 1c).

Feeding activity was significantly decreased $\left(\mathrm{F}_{(5,48)}=16.89, p<0.0001\right.$, Figure $\left.1 \mathrm{~b}\right)$ by Btk (LOEC= $12.5 \mathrm{mg}$ a.i $/ \mathrm{L}$ ) showing altered feeding rates of $-80 \%$ and $-90 \%$ after exposure to 12.5 and $25 \mathrm{mg}$ a.i./ $\mathrm{L}$, respectively. Again, feeding activity was not significantly affected by $\mathrm{Bb}$ concentrations compared to control treatment $\left(F_{(5,48)}=2.32, p=0.057\right.$, Figure $\left.1 d\right)$, despite the slight decrease observed.

The regeneration of blastema $\left(F_{(5,66)}=1.39, p=0.24\right.$, Figure 2a) and photoreceptors $(H=3.12, p=0.68$, Figure $2 b)$ were not significantly affected on planarians exposed to Btk when compared to control. However, length of blastema was significantly decreased on planarians exposed to Bb (Figure 2c) with LOEC of $0.75 \mathrm{mg} \mathrm{a.i} / \mathrm{L}$. Moreover, decreased length at $48 \mathrm{hrs}$ reached $-16.2,-15.4,-17.9$ and $-27.3 \%$ on planarians exposed to $0.75,1.5$, 
3, and $6 \mathrm{mg}$ a.i./L Bb, respectively $\left(\mathrm{F}_{(5,66)}=10.35, p<0.0001\right.$, Figure $\left.2 \mathrm{c}\right)$. In contrast, no significant differences were observed on the time needed for regeneration of photoreceptors $(H=4.34, p=0.50$, Figure $2 \mathrm{~d})$ on planarians exposed to $\mathrm{Bb}$.

Fecundity rate was significantly decreased after exposure of planarians to Btk with a LOEC of $3.12 \mathrm{mg}$ a.i/L ( $\mathrm{F}$ $(5,18)=19.51, p<0.0001$; Figure $3 a)$ and Bb with a LOEC of $1.5 \mathrm{mg} \mathrm{a.i/L}\left(\mathrm{F}_{(5,18)}=11.54, p<0.0001\right.$; Figure 3c). Fecundity rate reached a decrease of -64.2 on planarians exposed to the highest concentrations of Btk (Figure $3 a)$ and $-61.1 \%$ for $\mathrm{Bb}$ (Figure $3 \mathrm{c}$ ). However, fertility rate was not significantly affected on planarians exposed to $\mathrm{Btk}\left(\mathrm{F}_{(5,18)}=1.64, p=0.2\right.$; Figure $\left.3 \mathrm{~b}\right)$ and $\mathrm{Bb}\left(\mathrm{F}_{(5,18)}=2.40, p=0.07\right.$, Figure $\left.3 \mathrm{~d}\right)$, compared to respective control.

\section{Discussion}

Exposure to Btk- and Bb-based insecticides decreased the survival of planarians. However, only the estimated $\mathrm{LC}_{50}$ value for $\mathrm{Bb}$ was below the PECsw and the concentrations recommended for its application in the field (EFSA 2015; Agboyi et al. 2020). This shows that adults of G. tigrina, a non-target and non-insect species, seem to be very sensitive to formulations based on $\mathrm{Bb}$, but not so sensitive for Btk when compared to chironomids, Daphnia magna, the frog Leptodactylus latrans, and zebrafish (Table 1).

Survival tests performed with adults of $\mathrm{G}$. tigrina showed that Bb-based formulations increased the mortality of planarians at estimated PECsw demonstrating that care should be taken when using this bio-insecticide near aquatic ecosystems. Data on other aquatic invertebrates, besides insects, is still very scarce in the literature and further toxicity studies should be performed, since such formulations have not been considered to represent a risk to aquatic environments (EFSA 2012; EFSA 2013). Furthermore, the soil fungus $B$. bassiana is not considered a potential risk to aquatic compartments, which can also be a valuable reason for the limited number of studies found (EFSA 2013).

Although, $\mathrm{LC}_{50}$ data are a simple approach to assess the toxicity of Btk and Bb, it represents the first line of evidence for environmental risk assessment (Lajmanovich et al. 2015). In fact, endpoints assessed on planarians at the organismal and population levels showed to be much more sensitive than its survival, as expected according to Sokolova and co-workers (2012) and other studies previously performed with planarians (Ofoegbu et al. 2016; Rodrigues et al. 2016; Saraiva et al. 2018; Wu and Li 2018; López et al. 2019; Ofoegbu et al. 2019a, b; Saraiva et al. 2020; Dornelas et al. 2020b).

The microbial formulation based on Btk decreased the locomotion, feeding activity and fecundity of adult planarians for concentrations as low as $12.5,12.5$ and $3.12 \mathrm{mg}$ a.i./L, respectively. Nevertheless, these concentrations affecting behaviour and fecundity were still much higher than the PECsw value for Btk. In contrast, Bb-based formulation delayed the regeneration of blastema and decreased the fecundity of planarians at concentrations similar to the predicted environmental concentrations for surface water. Organisms exposed to moderate stress have high metabolic costs and high levels of energy consumption when trying to allocate energy to maintain defence mechanisms (Sokolova et al. 2012; Campos et al. 2017; Monteiro et al. 2019). No information of specific action mode of Btk or Bb regarding planarian's is available. However, exposure to bio-insecticides can interfere with the immune response of freshwater invertebrates 
exacerbated by decreased feeding activity, and consequently the allocation of energy to other physiological processes, in an attempt to overcome an inflammatory response (Bordalo et al. 2020).

Planarians have exceptionally robust regenerative abilities and regulate neoblasts' proliferation (stem cells) in response to changes in metabolic status and wounding (Elliott and Alvarado 2012; Rink 2013). Is intriguing that the delay in blastema' regeneration of adults was not enough to affect the regeneration of photoreceptors. Some xenobiotics can target very specific pathways, thus not affecting the planarian regeneration system (Hagstrom et al. 2015). The dissimilar responses on behavioural (affected by Btk) and regeneration (affected by $\mathrm{Bb}$, but not photoreceptor formation) endpoints are not surprising as they have distinct modes of action in insects (Sanahuja et al. 2011; Castagnola and Stock 2014; Mascarin and Jaronski 2016; Sayed and Behle 2017; Rustiguel et al. 2018; Bordalo et al. 2020). In this context, Bordalo et al. (2020) observed different responses between bio-insecticides-based $B$. thuringiensis and $B$. bassiana to life-history traits in $C$. riparius larvae. However, fecundity rate of planarians was also affected by both bio-insecticides showing that exposure to both formulations can induce adverse population level effects in planarians.

There is still scarce information on sub-lethtal effects of bio-insecticides on freshwater organisms and, to our knowledge, only a few studies were performed addressing development of larvae and emergence on Chironomus xanthus (Dornelas et al. 2020a, b) and Chironomus riparius (Charbonneau et al. 1994; Kästel et al. 2017; Bordalo et al. 2020). These previous studies with $C$. xanthus showed that Bt- and Bb-based formulations decreased growth rate of larvae and affected emergence, whereas Bt- did not affect time to emergence on study using $C$. riparius. Moreover, it was observed for insects that the toxicity of microbial insecticides may vary depending on the host species (Sanjayan et al. 1996; Beetz et al. 2008) and a few studies showed that this might be dependent on the mechanisms of response against bacterial and fungal and more specifically their immune response by recognition of microbial components and the triggering of a cascade of reactions leading to activation of phenoloxidase, that is crucial for the melanisation of pathogens and repair of damaged tissues (Cerenius et al. 2008; Grizanova et al. 2014). The host needs to cope also with reactive oxygen species and prevent oxidative damage as a consequence of immune response activation (González-Santoyo and Córdoba-Aguilar 2012; Saraiva et al. 2020).

Recent studies report the evaluation of the immune response of bio-insecticides based on $B$. thuringiensis and $B$. bassiana on $C$. xanthus (through total hemocyte count) and $C$. riparius (through Phenoloxidase activity) (Dornelas et al. 2020a; Bordalo et al. 2020). Phenoloxidase activity and oxidative damage has been previously assessed on planarians (Pang et al. 2010; Saraiva et al. 2020). Therefore, further research studies concerning the use of those biochemical endpoints would be desirable to further unravel the mechanisms of response of planarians to bacterial and fungal based insecticides, as well as, implications for consumption and allocation of energy. Interestingly, both microbial insecticides decreased the number of cocoons deposited by each planarian, but the number of newborns originated on each cocoon was not affected, showing that their development was not compromised by both formulations.

Overall, toxicity and sub-lethal effects of $B$. bassiana have been demonstrated at PECsw, that lead us to conclude that those formulations are not harmless to freshwater compartments and might not be safe to nontarget freshwater invertebrate species. Concerning Btk-based formulation, further studies should be pursued, since its use is increasing considerably and our current study showed deleterious effects on planarians' 
reproduction at much lower concentrations than the ones causing acute toxicity. Therefore, our study provides important information for the risk assessment of bio-insecticides in freshwater ecosystems. To our knowledge this is the first study concerning the reproductive effects of Btk - and Bb-based formulations in a non-target, non-insect freshwater invertebrate. Finally, the results obtained in this study are important to understand the possible direct effects of $B$. thuringiensis and $B$. bassiana on non-target aquatic organisms and validate the use of Girardia tigrina as a potential bioindicator species.

\section{Conclusions}

Our results showed evidence that microbial insecticides based on $\mathrm{Bb}$ might not be as ecologically friendly as previously suggested especially if used in the vicinity of aquatic ecosystems. This study also highlights the importance of using planarians as bioindicators of environmental contamination by bio-pesticides. Given the effects observed on fecundity rates of planarians exposed to environmentally relevant concentrations of $\mathrm{Bb}$ and Btk, it is critical to consider reproductive endpoints to better evaluate how microbial insecticides affect natural populations of non-target freshwater invertebrates.

\section{Declarations}

\section{Ethics approval and consent to participate}

'Not applicable'

\section{Consent for publication}

'Not applicable'

\section{Availability of data and materials}

The datasets used and/or analysed during the current study are available from the corresponding author on reasonable request.

\section{Competing interests}

The authors declare that they have no known competing financial interests or personal relationships that could have appeared to influence the work reported in this paper.

\section{Funding}

Coordenação de Aperfeiçoamento de Pessoal de Nível Superior-CAPES, Brazil (Edital 71/2013 - Programa Ciência Sem Fronteiras - Modalidade Pesquisador Visitante Especial-PVE - Projeto: A058_2013).

FCT/MCTES and CESAM (UIDP/50017/2020+UIDB/50017/2020), through national funds and the co-funding by the FEDER, within the PT2020 Partnership Agreement and Compete 2020. Conselho Nacional de Desenvolvimento Científico e Tecnológico-CNPq, Brazil (Produtividade em Pesquisa - Projeto: 306652/20188).

\section{Authors' contributions}


LCRS conducted experiments, analyzed data and wrote the manuscript (writing - original draft, review and editing). ASPD conducted experiments. ASS, ASPD, CG, JLTP, AMVMS and RAS analyzed data, review and edit the manuscript; RAS and AMVMS conceived (funding acquisition) and designed research. All authors read, made corrections, and approved the manuscript.

\section{Acknowledgements}

This work was supported by Coordenação de Aperfeiçoamento de Pessoal de Nível Superior-CAPES, Brazil (Edital 71/2013 - Programa Ciência Sem Fronteiras - Modalidade Pesquisador Visitante Especial-PVE Projeto: A058_2013). Thanks are due to FCT/MCTES for the financial support provided to CESAM (UIDP/50017/2020+UIDB/50017/2020), through national funds and the co-funding by the FEDER, within the PT2020 Partnership Agreement and Compete 2020. Renato A. Sarmento received a scholarship from Conselho Nacional de Desenvolvimento Científico e Tecnológico-CNPq, Brazil (Produtividade em Pesquisa Projeto: 306652/2018-8). The authors thank the Instituto Federal de Educação, Ciência e Tecnologia Goiano Campus Campos Belos, Brazil for its support and partnership.

\section{References}

1. Agboyi LK, Ketoh GK, Douro Kpindou OK, Martin T, Glitho IA, Tamo M (2020) Improving the efficiency of Beauveria bassiana applications for sustainable management of Plutella xylostella (Lepidoptera: Plutellidae) in West Africa. Biol Control 144:104233. https://doi.org/10.1016/j.biocontrol.2020.104233

2. Allgeier S, Kästel A, Brühl CA (2019) Adverse effects of mosquito control using Bacillus thuringiensis var. israelensis: Reduced chironomid abundances in mesocosm, semi-field and field studies. Ecotoxicol Environ Saf 169:786-796. https://doi.org/10.1016/j.ecoenv.2018.11.050

3. Álvarez B, Biosca EG (2017) Bacteriophage-based bacterial wilt biocontrol for an environmentally sustainable agriculture. Front Plant Sci 8:1218. https://doi.org/10.3389/fpls.2017.01218

4. ASTM (1980) Standard practice for conducting acute toxicity tests with fishes, macroinvertebrates and amphibians. Report E - 729-80. American Standards for Testing and Materials, Philadelphia

5. Beetz S, Holthusen TK, Koolman J, Trenczek T (2008) Correlation of hemocyte counts with different developmental parameters during the last larval instar of the tobacco hornworm, Manduca sexta. Arch Insect Biochem Physiol 67:63-75. https://doi.org/10.1002/arch.20221

6. Becker N, Margalit J (1993) Use of Bacillus thuringiensis israelensis against mosquitoes and blackflies. In: Entwistle PF, Cory JS, Bailey MJ, Higgs S (eds) Bacillus thuringiensis: An Environmental Biopesticide: Theory and Practice. John Wiley, Chichester, pp 147-170

7. Benzina F, Hamid S, Mohand-Kaci H, Bissaad F, Halouane F (2018) Histological changes in the larvae of the domestic mosquito Culex pipiens treated with the entomopathogenic fungus Beauveria bassiana. Sci Res Essays 13:1-10. https://doi.org/10.5897/SRE2017.6544

8. Berlitz DL, Knaak N, Cassal MC, Fiuza LM (2014) Bacillus and biopesticides in control of phytonematodes, In: Sahayaraj K (ed) Basic and Applied Aspects of Biopesticides. Springer publishers, pp 3-16. https://doi.org/10.1007/978-81-322-1877-7_1 
9. Bordalo MD, Gravato C, Beleza S, Campos D, Lopes I, Pestana JLT (2020) Lethal and sublethal toxicity assessment of Bacillus thuringiensis var. israelensis and Beauveria bassiana based bioinsecticides to the aquatic insect Chironomus riparius. Sci Total Environ 698:134155.

https://doi.org/10.1016/j.scitotenv.2019.134155

10. Campos D, Gravato C, Quintaneiro C, Golovko O, Žlábek V, Soares AMVM, Pestana JLT (2017) Toxicity of organic UV-filters to the aquatic midge Chironomus riparius. Ecotoxicol Environ Saf 143:210-216. https://doi.org/10.1016/j.ecoenv.2017.05.005

11. Cao CW, Sun LL, Wen RR, Li XP, Wu HQ, Wang ZY (2012) Toxicity and affecting factors of Bacillus thuringiensis var. israelensis on Chironomus kiiensis larvae. J insect Sci 12:126. https://doi.org/10.1673/031.012.12601

12. Castagnola A, Stock SP (2014) Common Virulence Factors and Tissue Targets of Entomopathogenic Bacteria for Biological Control of Lepidopteran Pests. Insects 5:139-166. https://doi.org/10.3390/insects5010139.

13. Cerenius L, Lee BL, Söderhäll K (2008) The proPO-system: pros and cons for its role in invertebrate immunity. Trends Immunol 29:263-271. https://doi.org/10.1016/j.it.2008.02.009

14. Challa GK, Firake DM, Behere GT (2019) Bio-pesticide applications may impair the pollination services and survival of foragers of honey bee, Apis cdrana fabricius in oilseed brassica. Environ Pollut 249:598609. https://doi.org/10.1016/j.envpol.2019.03.048

15. Charbonneau S, Drobney RD, Rabeni CF (1994) Effects of Bacillus thuringiensis var. israelensis on nontarget benthic organisms in a lentic habitat and factors affecting the efficacy of the larvicide. Environ Toxicol Chem 13:267-279. https://doi.org/10.1002/etc.5620130211

16. Dornelas ASP, Sarmento RA, Silva LCR, Saraiva AS, Souza DJ, Bordalo MD, Soares AVMM, Pestana JLT

17. a) Toxicity of microbial insecticides towards the non-target freshwater insect Chironomus xanthus. Pest Manag Sci 76:1-27. https://doi.org/10.1002/ps.5629

18. Dornelas ASP, Sarmento RA, Cavallini GS, Barbosa RS, Vieira MM, Saraiva AS, Bordalo MD, Soares AMVM, Pestana JLT (2020b) Lethal and sublethal effects of the saline stressor sodium chloride on Chironomus xanthus and Girardia tigrina. Environ Sci Pollut Res 1-11. https://doi.org/10.1007/s11356-020-09556-9

19. EFSA - European Food Safety Authority (2012) Conclusion on the peer review of the pesticide risk assessment of the active substance Bacillus thuringiensis subsp. kurstaki (strains ABTS 351, PB 54, SA 11, SA 12, EG 2348). EFSA Journal 10:1-66. https://doi.org/10.2903/j.efsa.2012.2540

20. EFSA - European Food Safety Authority (2013) Conclusion on the Peer Review of the Pesticide Risk Assessment of the Active Substances Beauveria bassiana Strains ATCC-74040 and GHA. https://doi.org/10.2903/j.efsa.2010.1708

21. EFSA - European Food Safety Authority (2015) Peer review of the pesticide risk assessment of the active substance Beauveria bassiana strain 147. EFSA Journal 13:10. https://doi.org/10.2903/j.efsa.2015.4261

22. Elliott SA, Sanchez Alvarado A (2013) The history and enduring contributions of planarians to the study of animal regeneration. Wiley Interdiscip Rev Dev Biol 2:301-326. https://doi.org/10.1002/wdev.82

23. EPA - U.S. Environmental Protection Agency (2016) Ingredients Used in Pesticide Products. Available in: https://www.epa.gov/ingredients-used-pesticide-products/what-are-biopesticides. Accessed on June 04, 
2020

24. Genthner FJ, Cripe GM, Crosby DJ (1994) Effect of Beauveria bassiana and its toxins on Mysidopsis bahia (Mysidacea). Archs. environ. Contam Toxicol 26:90-94. https://doi.org/10.1007/BF00212798

25. González-Santoyo I, Córdoba-Aguilar A (2012) Phenoloxidase: a key component of the insect immune system. Entomol Exp Appl 142:1-16. https://doi.org/10.1111/ j.1570-7458.2011.01187.x

26. Grizanova EV, Dubovskiy IM, Whitten MMA, Glupov VV (2014) Contributions of cellular and humoral immunity of Galleria mellonella larvae in defence against oral infection by Bacillus thuringiensis. J Invertebr Pathol 119:40-46. https://doi.org/10.1016/ j.jip.2014.04.003

27. Grisolia CK, Oliveira R, Domingues I, Oliveira-Filho EC, Monerat RG, Soares AMVM (2009) Genotoxic evaluation of different $\delta$-endotoxins from Bacillus thuringiensis on zebrafish adults and development in early life stages. Mutat Res Genet Toxicol Environ Mutagen 672:119-123.

https://doi.org/10.1016/j.mrgentox.2008.10.017

28. Guecheva TN, Erdtmann B, Benfato MS, Henriques JAP (2003) Stress protein response and catalase activity in freshwater planarian Dugesia (Girardia) schubarti exposed to copper. Ecotox Environ Safe 56:351-357. https://doi.org/10.1016/S0147-6513(02)00065-9

29. Gupta S, Dikshit AK (2010) Biopesticides: An eco-friendly approach for pest control. J Biopestic 3:186188

30. Hagstrom D, Cochet-Escartin O, Zhang S, Khuu C, Collins EMS (2015) Freshwater planarians as an alternative animal model for neurotoxicology. Toxicol Sci 147:270-285.

https://doi.org/10.1093/toxsci/kfv129

31. Hart DD, Merz RA (1998) Predator-prey interactions in a benthic stream community: a field test oflowmediated refuges. Oecologia 114:263-273. https://doi.org/10.1007/s004420050445

32. Hughes P, Stevens M, Park H, Federici B, Dennis E, Akhurst R (2005) Response of larval Chironomus tepperi (Diptera: Chironomidae) to individual Bacillus thuringiensis var. Israelensis toxins and toxin mixtures. J Invertebr Pathol 88:34-39. https://doi.org/10.1016/j.jip.2004.10.004

33. Kandpal V (2014) Biopesticides. Int J Environ Res Develop 4:191-196

34. Karmrin MA (1997) Pesticide Profiles: Toxicity, Environmental Impact, and Fate. Lewis Publishers/CRC Press, Boca Raton

35. Kästel A, Allgeier S, Brühl CA (2017) Decreasing Bacillus thuringiensis israelensis sensitivity of Chironomus riparius larvae with age indicates potential environmental risk for mosquito control. Sci Rep 7:1-7. https://doi.org/10.1038/s41598-017-14019-2

36. Khawaled K, Ben-Dov E, Zaritsky A, Barak Z (1990) The fate of Bacillus thuringiensis var. israelensis in B. thuringiensis var. israelensis-killed pupae of Aedes aegypti. J Invertebr Pathol 56:312-316. https://doi.org/10.1016/0022-2011(90)90117-0.

37. Knakievicz T, Ertdmann B, Vieira SM, Ferreira HB (2006) Reproduction modes and life cycle of freshwater planarians (Plathyhelminthes, Tricladida, Paludicula) from Southern Brazil. Invertebr Biol 125:212-221. https://doi.org/10.1111/j.1744-7410.2006.00054.x

38. Knakievicz T, Ferreira H (2008) Evaluation of copper effects upon Girardia tigrina freshwater planarians based on a set of biomarkers. Chemosphere 71:419-428. 
https://doi.org/10.1016/j.chemosphere.2007.11.004

39. Knakievicz T (2014) Planarians as invertebrate bioindicators in freshwater environmental quality: the biomarkers approach. Ecotoxicol Environ Contam 9:1-12. http://doi.org/10.5132/eec.2014.01.001

40. Kumar S (2015) Biopesticide: An environment friendly pest management strategy. J Biofertil Biopestici 6:3. https://doi.org/10.4172/2155-6202.1000e127

41. Lajmanovich RC, Junges CM, Cabagna-Zenklusen MC, Attademo AM, Peltzer PM, Maglianese M, Márquez VE, Beccaria AJ (2015) Toxicity of Bacillus thuringiensis var. israelensis in aqueous suspension on the South American common frog Leptodactylus latrans (Anura: Leptodactylidae) tadpoles. Environ Res 136:205-212. https://doi.org/10.1016/j.envres.2014.10.022

42. Lavarías S, Arrighetti F, Siri A (2017) Histopathological effects of cypermethrin and Bacillus thuringiensis var. israelensis on midgut of Chironomus calligraphus larvae (Diptera: Chironomidae). Pestic Biochem Physiol 139:9-16. https://doi.org/10.1016/j.pestbp.2017.04.002

43. Lee BM, Scott GI (1989) Acute toxicity of temephos, fenoxycarb, diflubenzuron, and methoprene and Bacillus thuringiensis var. israelensis to the mummichog (Fundulus heteroclitus). Bull Environ Contam Toxicol 43:827-832. https://doi.org/10.1007/bf01702051

44. López AMC, Sarmento RA, Saraiva AS, Pereira RR, Soares AMVM, Pestana JLT (2019) Exposure to Roundup ${ }^{\circledR}$ affects behaviour, head regeneration and reproduction of the freshwater planarian Girardia tigrina. Sci Total Environ 675:453-461. https://doi.org/10.1016/j.scitotenv.2019.04.234

45. Machado AAS, Zarfl C, Rehse S, Kloas W (2017) Low-dose effects: nonmonotonic responses for the toxicity of a Bacillus thuringiensis biocide to Daphnia magna. Environ Sci Technol 51:1679-1686. https://doi.org/10.1021/acs.est.6b03056

46. Mascarin GM, Jaronski ST (2016) The production and uses of Beauveria bassiana as a microbial insecticide. World J Microbiol Biotechnol 32:177. https://doi.org/10.1007/s11274-016-2131-3

47. Mazid S, Rajkhowa RC, Kalita JC (2011) A review on the use of biopesticides in insect pest management. Int J Sci Adv Technol 1:169-178

48. McConnell JV (1965) On the procuring and the care of planarians. In: McConnell JV (ed) A manual of psychological experiments on planarians: The Worm Runner's Digest. Ann Arbor, Michigan, pp 10-20

49. Monteiro HR, Pestana JLT, Novais SC, Soares AMVM, Lemos MFL (2019) Toxicity of the insecticides spinosad and indoxacarb to the non-target aquatic midge Chironomus riparius. Sci Total Environ 666:1283-1291. https://doi.org/10.1016/j.scitotenv.2019.02.303

50. OECD - Organisation for Economic Co-operation and Development (2012) Working Document to the Environmental Safety Evaluation of Microbial Biocontrol Agents. Series on Pesticides, n. 67

51. Ofoegbu PU, Simão FCP, Cruz A, Mendo S, Soares AMVM, Pestana JLT (2016) Toxicity of tributyltin (TBT) to the freshwater planarian Schmidtea mediterranea. Chemosphere 148:61-67. https://doi.org/10.1016/j.chemosphere.2015.12.131

52. Ofoegbu PU, Campos D, Soares AMVM, Pestana JLT (2019a) Combined effects of NaCl and fluoxetine on the freshwater planarian, Schmidtea mediterranea (Platyhelminthes: Dugesiidae). Environ Sci Pollut R 26:11326-11335. https://doi.org/10.1007/s11356-019-04532-4 
53. Ofoegbu OU, Lourenço J, Mendo S, Soares AMVM, Pestana JLT (2019b) Effects of low concentrations of psychiatric drugs (carbamazepine and fluoxetine) on the freshwater planarian, Schmidtea mediterrânea. Chemosphere 217:542-549. https://doi.org/10.1016/j.chemosphere.2018.10.198

54. Olson S (2015) An analysis of the biopesticide market now and where it is going. Outlooks Pest Manag 26:203-206. https://doi.org/10.1564/v26_oct_04

55. Pang Q, Liu X, Zhao B, Jiang Y, Su F, Zhang X, Nie M, Zhang M, Sun H (2010) Detection and characterization of phenoloxidase in the freshwater planarian Dugesia japonica. Comp Biochem Phys B Biochemistry Molecular Biology 157:54-58. https://doi.org/10.1016/j.cbpb.2010.05.002

56. Pelizza S, Scorsetti A, Bisaro V, L'opez LC, García J (2010) Individual and combined effects of Bacillus thuringiensis var. Israelenses, temephos and Leptolegnia chapmanii on the larval mortality of Aedes aegypti. Biocontrol 55:647-656. https:// doi.org/10.1007/s10526-010-9281-2

57. Ragavendran C, Dubey NK, Natarajan D (2017) Beauveria bassiana (Clavicipitaceae): a potent fungal agent for controlling mosquito vectors of Anopheles stephensi, Culex quinquefasciatus and Aedes aegypti (Diptera. Culicidae). RSC Adv 7:3838-3851. https://doi.org/10.1039/C6RA25859J

58. Reddien PW, Alvarado AS (2004) Fundamentals of Planarian Regeneration. Annu Rev Cell Dev Bi 20:725757. https://doi.org/10.1146/annurev.cellbio.20.010403.095114

59. Rehner SA, Minnis AM, Sung GH, Luangsa-ard JJ, Devotto L, Humber RA (2011) Phylogeny and systematics of the anamorphic, entomopathogenic genus Beauveria. Mycologia 103:1055-1073. https://doi.org/10.3852/10-302

60. Rink J (2013) Stem cell systems and regeneration in planaria. Dev Gene Evol 223:67-84. https://doi.org/10.1007/s00427-012-0426-4

61. Rodrigues ACM, Henriques JF, Domingues I, Golovkob O, Zlábek V, Barata C, Soares AMVM, Pestana JLT (2016) Behavioural responses of freshwater planarians after short-termexposure to the insecticide chlorantraniliprole. Aquat Toxicol 170:371-376. https://doi.org/10.1016/j.aquatox.2015.10.018

62. Rustiguel CB, Fernández-Bravo M, Guimarães LHS, Quesada-Moraga E (2018) Different strategies to kill the host presented by Metarhizium anisopliae and Beauveria bassiana. Can J Microbiol 64:191-200. https://doi.org/10.1139/cjm-2017-0517

63. Sanahuja G, Banakar R, Twyman RM, Capell T, Christou P (2011) Bacillus thuringiensis: a century of research, development and commercial applications. Plant Biotechnol J 9:283-300. https://doi.org/10.1111/j.1467-7652.2011.00595.x

64. Sandhu SS, Sharma AK, Beniwal V, Goel G, Batra P, Kumar A, Jaglan S, Sharma AK, Malhotra S (2012) Myco-biocontrol of insect pests: factors involved, mechanism, and regulation. J Pathog 2012:1-10. https://doi.org/10.1155/2012/126819.

65. Sanjayan KP, Ravikumar T, Albert S (1996) Changes in the haemocyte profile of Spilostethus hospes (Fab) (Heteroptera: Lygaeidae) in relation to eclosion, sex and mating. J Biosci 21:781-788. https://doi.org/10.1007/BF02704719. 0

66. Saraiva AS, Sarmento RA, Golovko O, Randak T, Pestana JLT, Soares AMVM (2018) Lethal and sub-lethal effects of cyproconazole on freshwater organisms: a case study with Chironomus riparius and Dugesia tigrina. Environ Sci Pollut Res 25:12169-12176. https://doi.org/10.1007/s11356-017-1180-y 
67. Saraiva AS, Sarmento RA, Gravato C, Rodrigues ACM, Campos D, Simão FCP, Soares AMVM (2020) Strategies of cellular energy allocation to cope with paraquat-induced oxidative stress: Chironomids vs planarians and the importance of using different species. Sci Total Environ 741:140443.

https://doi.org/10.1016/j.scitotenv.2020.140443

68. Sayed AMM, Behle RW (2017) Evaluating a dual microbial agent biopesticide with Bacillus thuringiensis var. kurstaki and Beauveria bassiana blastospores. Biocontrol Sci Technol 27:461-474. https://doi.org/10.1080/09583157.2017.1303662

69. Simão FCP, Gravato C, Machado AL, Soares AMVM, Pestana JLT (2020) Toxicity of different polycyclic aromatic hydrocarbons (PAHs) to the freshwater planarian Girardia tigrina. Environ Pollut 266:115185. https://doi.org/10.1016/j.envpol.2020.115185

70. Simão FCP, Gravato C, Machado AL, Soares AMVM, Pestana JLT (2021) Effects of pyrene and benzo[a]pyrene on the reproduction and newborn morphology and behavior of the freshwater planarian Girardia tigrina. Chemosphere 264:128448. https://doi.org/10.1016/j.chemosphere.2020.128448

71. Singh RK, Dhama K, Khandia R, Munjal A, Karthik K, Tiwari R, Chakraborty S, Malik YS, Bueno-Mara RP (2018) Prevention and control strategies to counter Zika virus, a special focus on intervention approaches against vector mosquitoes-current updates. Front Microbiol 9:87.

https://doi.org/10.3389/fmicb.2018.00087

72. Sokolova IM, Frederich M, Bagwe R, Lannig G, Sukhotin AA (2012) Energy homeostasis as an integrative tool for assessing limits of environmental stress tolerance in aquatic invertebrates. Mar Environ Res 79:1-15. https://doi.org/10.1016/j.marenvres.2012.04.003

73. Subbanna ARNS, Stanley J, Rajasekhara H, Mishra KK, Pattanayak A, Bhowmick R (2019) Perspectives of microbial metabolites as pesticides in agricultural pest management. In: Merillon JM, Ramawat KG (eds) Co-evolution of secondary metabolites. Reference Series in Phytochemistry, Springer, Cham, pp 1-28

74. Thakore T (2006) The biopesticide market for global agricultural use. Ind Biotechnol 2:194-208

75. Tyler MS (2000) Planarian Regeneration. In: Sundderland MA (ed) Developmental Biology: a guide for experimental study, 2 edn. Sinauer Associates, Inc Publishers, pp 163-175

76. Vila-Farré M, Rink JC (2018) The ecology of freshwater planarians. In: Jochen C, Rink (eds) Planarian Regeneration: Methods and Protocols, Methods in Molecular Biology. Humana Press, New York, pp 173205

77. Vivekanandhan P, Kavitha T, Karthi S, Senthil-Nathan S, Shivakumar MS (2018) Toxicity of Beauveria bassiana - 28 Mycelial Extracts on Larvae of Culex quinquefasciatus Mosquito (Diptera: Culicidae). Int J Environ Res Public Health 15:440. https://doi.org/10.3390/ijerph15030440

78. WHO - World Health Organization (1999) Microbial Pest Control Agent: Bacillus thuringiensis. Environmental Health Criteria 217. World Health Organization, Geneva, witzerland

79. Wu JP, Li MH (2018) The use of freshwater planarians in environmental toxicology studies: Advantages and potential. Ecotoxicol Environ Saf 161:45-56. https://doi.org/10.1016/j.ecoenv.2018.05.057

80. Zimmermann G (2007) Review on safety of the entomopathogenic fungi Beauveria bassiana and Beauveria brongniartii. Biocontrol Sci Technol 17:553-596. https://doi.org/10.1080/09583150701309006 Captions 


\section{Tables}

Table 1: Acute toxicity of $B$. thuringiensis and B. bassiana to aquatic organisms. 


\begin{tabular}{|c|c|c|c|c|c|}
\hline $\begin{array}{l}\text { Microbial } \\
\text { Insecticide }\end{array}$ & Species & Life stage & $\begin{array}{l}\text { Test } \\
\text { duration }\end{array}$ & $\begin{array}{l}\mathrm{LC}_{50} \\
\text { or } \mathrm{EC}_{50}\end{array}$ & Reference \\
\hline
\end{tabular}

\section{Aquatic Invertebrates}

\begin{tabular}{|c|c|c|c|c|c|}
\hline $\begin{array}{l}B . \\
\text { thuringiensis }\end{array}$ & Chironomus xanthus & $\begin{array}{l}\text { Insect larvae } \\
\text { (non-target) - 1st } \\
\text { instar }\end{array}$ & 48 hours & $\begin{array}{l}\mathrm{LC}_{50}= \\
1534 \mu \mathrm{g} \\
\text { a.i./L }\end{array}$ & $\begin{array}{l}\text { Dornelas et al. } \\
(2020 a)\end{array}$ \\
\hline $\begin{array}{l}\text { B. } \\
\text { thuringiensis }\end{array}$ & Chironomus riparius & $\begin{array}{l}\text { Insect larvae } \\
\text { (non-target) - 1st } \\
\text { instar }\end{array}$ & 48 hours & $\begin{array}{l}\mathrm{LC}_{50}= \\
1.8 \mu \mathrm{g} \\
\text { a.i./L }\end{array}$ & $\begin{array}{l}\text { Bordalo et al. } \\
\text { (2020) }\end{array}$ \\
\hline $\begin{array}{l}B . \\
\text { thuringiensis }\end{array}$ & Chironomus riparius & $\begin{array}{l}\text { Insect larvae } \\
\text { (non-target) - 1st } \\
\text { instar }\end{array}$ & 48 hours & $\begin{array}{l}\mathrm{LC}_{50}= \\
2.3 \mu \mathrm{g} \\
\text { a.i./L }\end{array}$ & $\begin{array}{l}\text { Kästel et al. } \\
(2017)\end{array}$ \\
\hline $\begin{array}{l}\text { B. } \\
\text { thuringiensis }\end{array}$ & Chironomus calligraphus & $\begin{array}{l}\text { Insect larvae } \\
\text { (non-target) - } \\
\text { 3rd/4th instar }\end{array}$ & 48 hours & $\begin{array}{l}\mathrm{LC}_{50}= \\
11.2 \mu \mathrm{g} \\
\text { a.i./L }\end{array}$ & $\begin{array}{l}\text { Lavarías et al. } \\
\text { (2017) }\end{array}$ \\
\hline $\begin{array}{l}\text { B. } \\
\text { thuringiensis }\end{array}$ & Chironomus tepperi & $\begin{array}{l}\text { Insect larvae } \\
\text { (non-target) - 4th } \\
\text { instar }\end{array}$ & 48 hours & $\begin{array}{l}\mathrm{LC}_{50}= \\
40- \\
48 \mu \mathrm{g} \\
\text { a.i./L }\end{array}$ & $\begin{array}{l}\text { Hughes et al. } \\
(2005)\end{array}$ \\
\hline $\begin{array}{l}\text { B. } \\
\text { thuringiensis }\end{array}$ & Chironomus kiiensis & $\begin{array}{l}\text { Insect larvae } \\
\text { (non-target) - 4th } \\
\text { instar }\end{array}$ & 24 hours & $\begin{array}{l}\mathrm{LC}_{50}= \\
0.3- \\
1.6 \mathrm{mg} \\
\text { a.i./L }\end{array}$ & $\begin{array}{l}\text { Cao et al. } \\
(2012)\end{array}$ \\
\hline $\begin{array}{l}B . \\
\text { thuringiensis }\end{array}$ & Daphnia magna & $\begin{array}{l}\text { Planktonic } \\
\text { crustacean } \\
\text { (non-target) } \leq \\
24 \text { h old }\end{array}$ & 48 hours & $\begin{array}{l}\mathrm{EC}_{50}= \\
0.15 \mu \mathrm{g} \\
\text { a.i./L }\end{array}$ & $\begin{array}{l}\text { Machado et al. } \\
(2017)\end{array}$ \\
\hline $\begin{array}{l}\text { B. } \\
\text { thuringiensis }\end{array}$ & Aedes aegypti & $\begin{array}{l}\text { Insect larvae - } \\
\text { 4th instar }\end{array}$ & 24 hours & $\begin{array}{l}\mathrm{LC}_{50} \\
=600 \\
\text { spores } / \mathrm{ml}\end{array}$ & $\begin{array}{l}\text { Khawaled et al. } \\
(1990)\end{array}$ \\
\hline B. bassiana & Chironomus xanthus & $\begin{array}{l}\text { Insect larvae } \\
\text { (non-target) - } \\
\text { 1st instar }\end{array}$ & 48 hours & $\begin{array}{l}\mathrm{LC}_{50}= \\
6.3 \mu \mathrm{g} \\
\text { a.i./L }\end{array}$ & $\begin{array}{l}\text { Dornelas et al. } \\
\text { (2020a) }\end{array}$ \\
\hline B. bassiana & Chironomus riparius & $\begin{array}{l}\text { Insect larvae } \\
\text { (non-target) - 1st } \\
\text { instar }\end{array}$ & 48 hours & $\begin{array}{l}\mathrm{LC}_{50}= \\
34.7 \mathrm{mg} \\
\text { a.i./L }\end{array}$ & $\begin{array}{l}\text { Bordalo et al. } \\
(2020)\end{array}$ \\
\hline B. bassiana & Anopheles stephensi & Insect larvae - & 24 hours & $\mathrm{LC}_{50}=$ & Ragavendran \\
\hline
\end{tabular}




\begin{tabular}{|c|c|c|c|c|c|}
\hline & & 4th instar & & $\begin{array}{l}32.6 \mathrm{mg} \\
\text { a.i./L }\end{array}$ & et al. (2017) \\
\hline B. bassiana & $\begin{array}{l}\text { Culex } \\
\text { quinquefasciatus }\end{array}$ & $\begin{array}{l}\text { Insect larvae - } \\
\text { 4th instar }\end{array}$ & 24 hours & $\begin{array}{l}\mathrm{LC}_{50}= \\
\text { 35.4 mg } \\
\text { a.i./L }\end{array}$ & $\begin{array}{l}\text { Ragavendran } \\
\text { et al. (2017) }\end{array}$ \\
\hline B. bassiana & $\begin{array}{l}\text { Culex } \\
\text { quinquefasciatus }\end{array}$ & $\begin{array}{l}\text { Insect larvae - } \\
1 \text { st instar }\end{array}$ & 24 hours & $\begin{array}{l}\mathrm{LC}_{50}= \\
11.53 \mathrm{mg} \\
\text { a.i./L }\end{array}$ & $\begin{array}{l}\text { Vivekanandhan } \\
\text { et al. (2018) }\end{array}$ \\
\hline B. bassiana & Aedes aegypti & $\begin{array}{l}\text { Insect larvae - } \\
\text { 4th instar }\end{array}$ & 24 hours & $\begin{array}{l}\mathrm{LC}_{50}= \\
47.1 \mathrm{mg} \\
\text { a.i./L }\end{array}$ & $\begin{array}{l}\text { Ragavendran } \\
\text { et al. (2017) }\end{array}$ \\
\hline B. bassiana & Mysidopsis bahia & $\begin{array}{l}\text { shrimp/juveniles } \\
\text { (non-target) } \leq \\
24 \text { h old }\end{array}$ & 96 hours & $\begin{array}{l}\mathrm{LC}_{50}= \\
560 \mu \mathrm{g} \\
\text { a.i. } / \mathrm{L}\end{array}$ & $\begin{array}{l}\text { Genthner et al. } \\
\text { (1994) }\end{array}$ \\
\hline \multicolumn{6}{|c|}{ Aquatic Vertebrates } \\
\hline $\begin{array}{l}B \text {. } \\
\text { thuringiensis }\end{array}$ & Leptodactylus latrans & $\begin{array}{l}\text { amphibian (non- } \\
\text { target) - larvae }\end{array}$ & 48 hours & $\begin{array}{l}\mathrm{LC}_{50}= \\
\text { 22.45 mg } \\
\text { a.i./L }\end{array}$ & $\begin{array}{l}\text { Lajmanovich et } \\
\text { al. (2015) }\end{array}$ \\
\hline $\begin{array}{l}B \text {. } \\
\text { thuringiensis }\end{array}$ & Danio rerio & $\begin{array}{l}\text { Zebrafish (non- } \\
\text { target) } \\
\text { - embryos and } \\
\text { larvae }\end{array}$ & 96 hours & $\begin{array}{l}\mathrm{LC}_{50}= \\
85.9- \\
188.4 \mathrm{mg} \\
\text { a.i./L }\end{array}$ & $\begin{array}{l}\text { Grisolia et al. } \\
(2009)\end{array}$ \\
\hline $\begin{array}{l}B . \\
\text { thuringiensis }\end{array}$ & Fundulus heteroclitus & $\begin{array}{l}\text { Fish (non-target) } \\
\text { - Adult }\end{array}$ & 96 hours & $\begin{array}{l}\mathrm{LC}_{50}= \\
980 \mathrm{mg} \\
\text { a.i./L }\end{array}$ & $\begin{array}{l}\text { Lee and Scott } \\
\text { (1989) }\end{array}$ \\
\hline $\begin{array}{l}\text { B. } \\
\text { thuringiensis }\end{array}$ & Oncorhynchus mykiss & $\begin{array}{l}\text { Rainbow trout } \\
\text { (non-target) }\end{array}$ & 32 days & $\begin{array}{l}\mathrm{LC}_{50}> \\
143.5 \\
\text { MPCA/L* }\end{array}$ & EFSA (2012) \\
\hline $\begin{array}{l}B \text {. } \\
\text { thuringiensis }\end{array}$ & Lepomis macrochirus & $\begin{array}{l}\text { Bluegill Sunfish } \\
\text { (non-target) }\end{array}$ & 32 days & $\begin{array}{l}\mathrm{LC}_{50}> \\
143.5 \\
\text { MPCA/L* }\end{array}$ & EFSA (2012) \\
\hline B. bassiana & Oncorhynchus mykiss & $\begin{array}{l}\text { Rainbow trout } \\
\text { (non-target) - } \\
\text { embryos, larvae } \\
\text { and adult }\end{array}$ & 31 days & $\begin{array}{l}\mathrm{LC}_{50}= \\
7300 \mathrm{mg} \\
\text { a.i./L }\end{array}$ & $\begin{array}{l}\text { Zimmermann } \\
(2007)\end{array}$ \\
\hline
\end{tabular}

* Microbial Pest Control Agent (MPCA) = Active Ingredient. 
Figures

a)

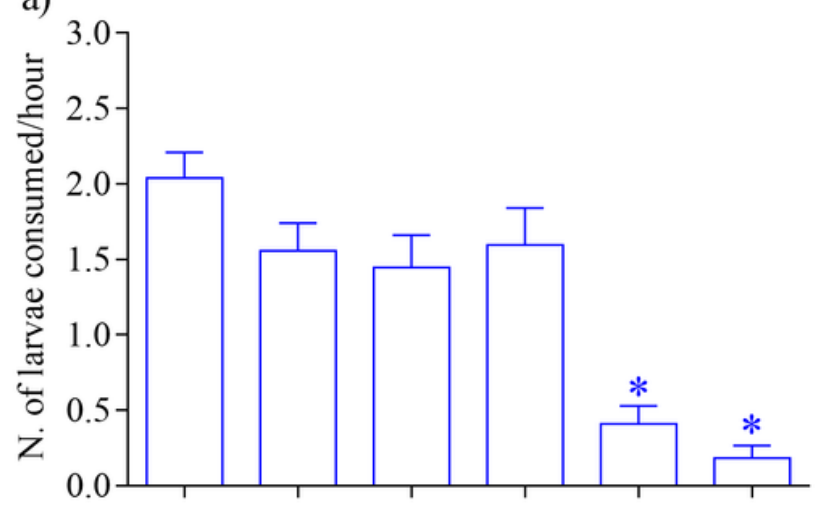

b)

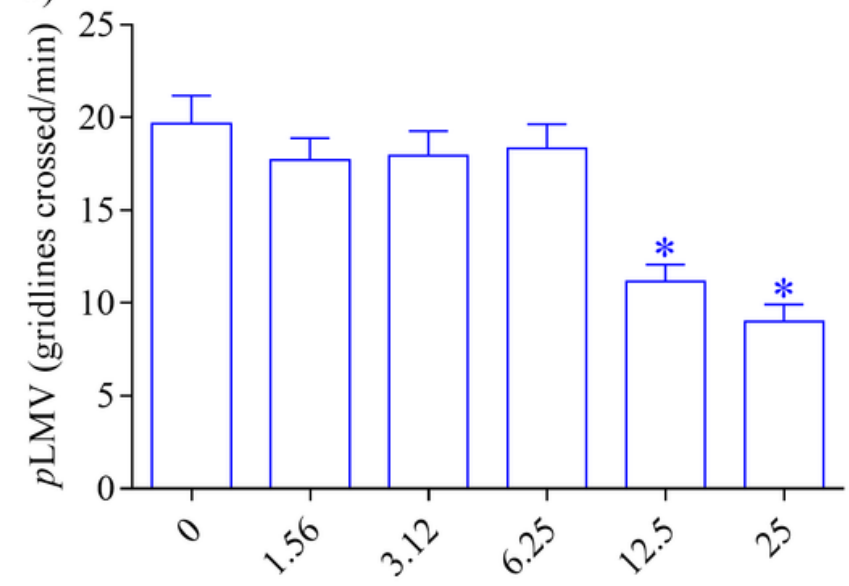

B. thuringiensis concentrations (mg a.i./L ) c)

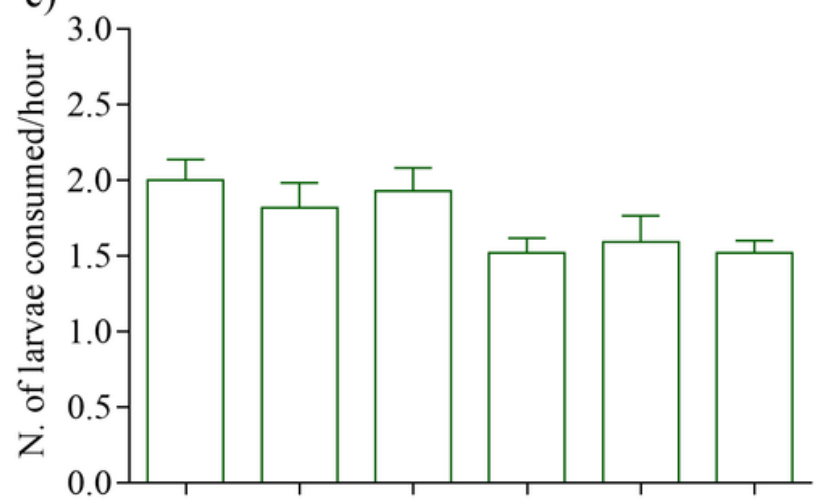

d)

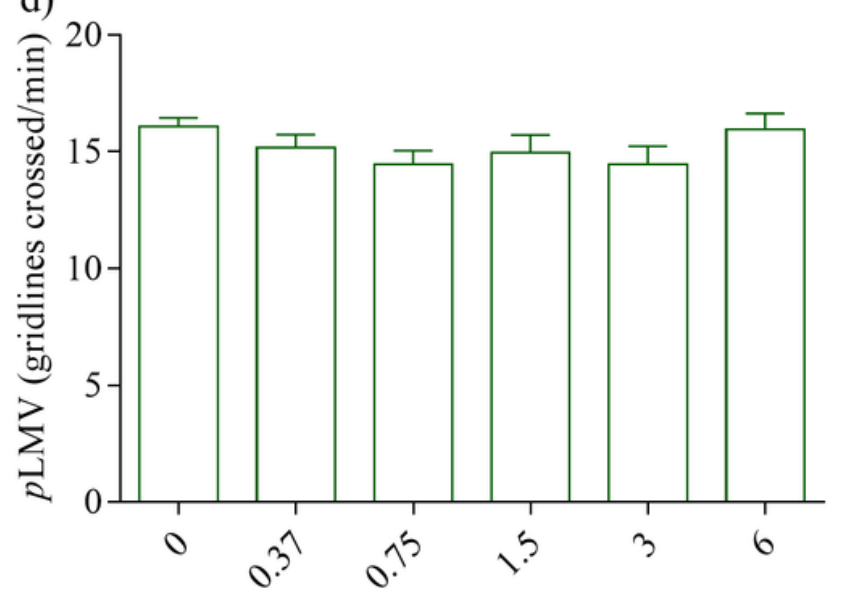

B. bassiana concentrations (mg a.i./L)

Figure 1

Feeding rate of $\mathrm{G}$. tigrina (number of $\mathrm{C}$. xanthus larvae totally consumed per hour; mean \pm SEM) after exposure to sub lethal concentrations of B. thuringiensis [a)] and B. bassiana [c)]. Locomotor velocity of $G$. tigrina (gridlines crossed per minute; mean \pm SEM) after exposure to sub lethal concentrations of $B$. thuringiensis [b)] and B. bassiana [d)]. *Denotes significant differences compared to the control treatment (Dunnett's test) 
a)

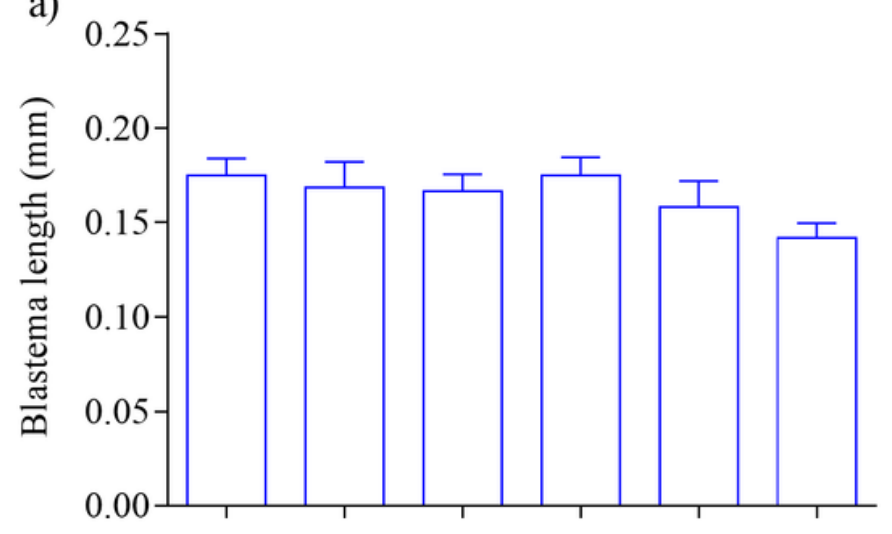

b)

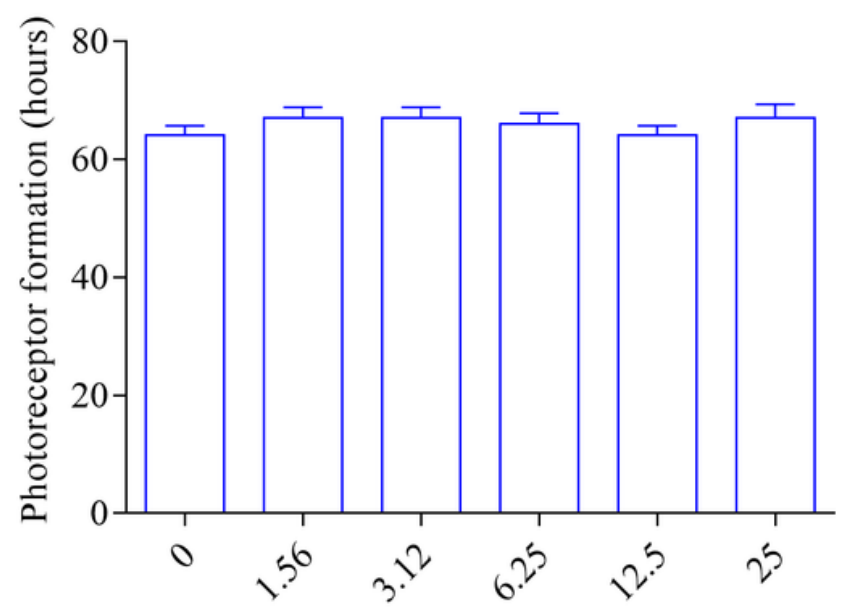

B. thuringiensis concentrations (mg a.i./L)

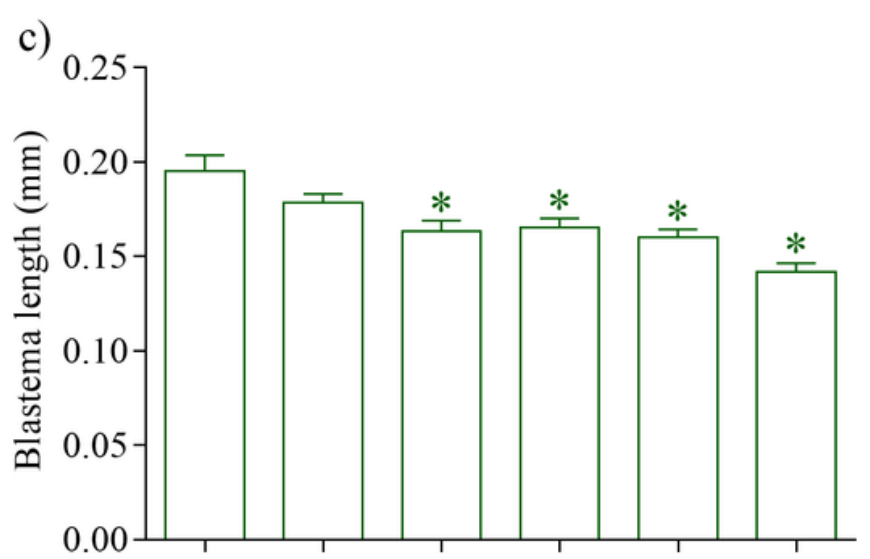

d)

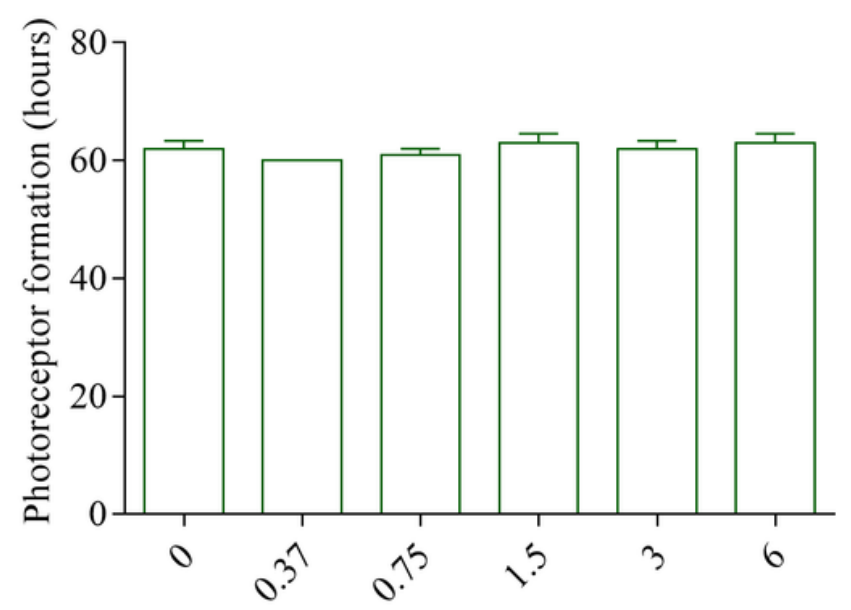

B. bassiana concentrations (mg a.i./L)

\section{Figure 2}

Blastema regeneration ( $\mathrm{mm}$ - after 48 hours of decapitation; mean \pm SEM) of G. tigrina after exposure to sublethal concentrations of B. thuringiensis [a)] and B. bassiana [c)]; Photoreceptor formation (hours; mean \pm SEM) of G. tigrina after exposure to sub-lethal concentrations of B. thuringiensis [b)] and B. bassiana [d)]. *Denotes significant differences compared to the control treatment (Dunnett's test) 
a)

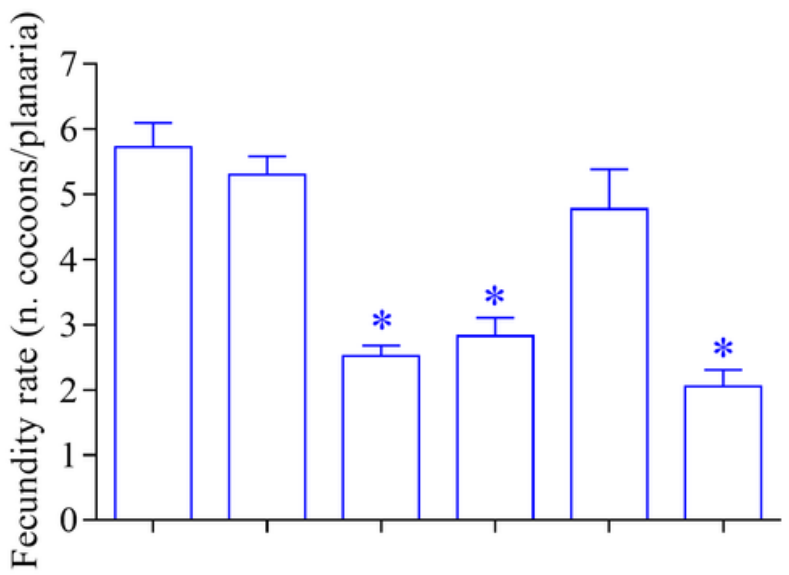

b)

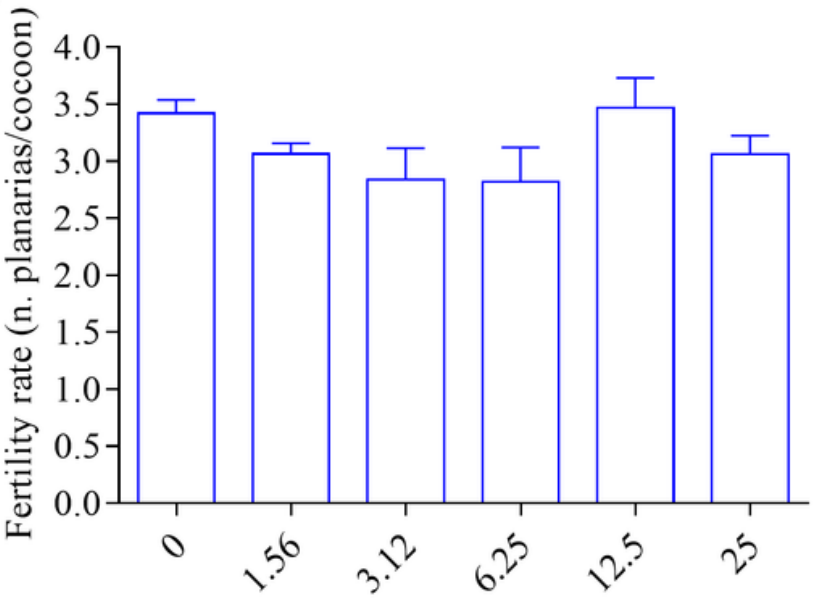

B. thuringiensis concentrations (mg a.i./L) c)

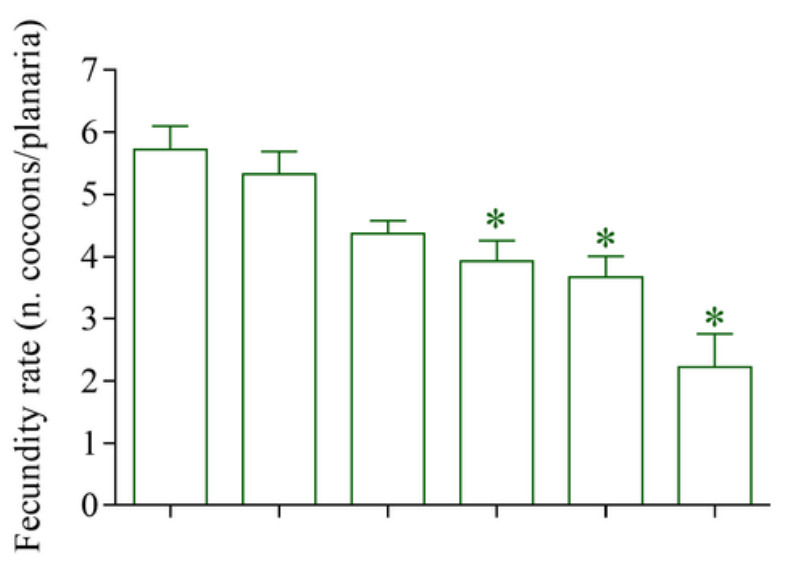

d)

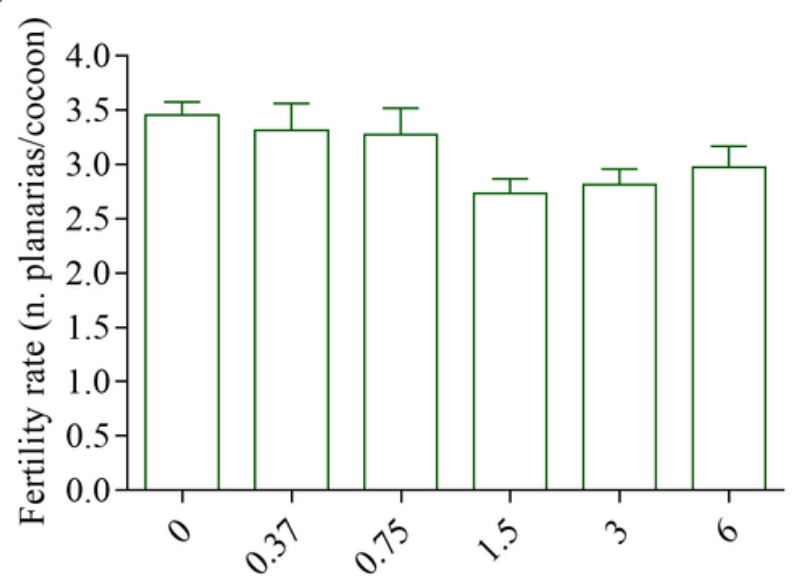

B. bassiana concentrations (mg a.i./L)

Figure 3

Fecundity rate (mean \pm SEM) of G. tigrina exposed during four weeks to sub-lethal concentrations of $B$. thuringiensis [a)] and B. bassiana [c)]. Fertility rate (mean \pm SEM) of G. tigrina exposed during four weeks to sub-lethal concentrations of B. thuringiensis [b)] and B. bassiana [d)]. *Denotes significant difference compared to the control treatment (Dunnett's test) 